\title{
Dynamic changes and genotypic variations of nitrogen concentration and remobilization for 20 tea plant (Camellia sinensis) cultivars throughout growing seasons
}

\section{Yange Zhang \\ Huazhong Agriculture University College of Horticulture and Forestry Sciences \\ Xiangsheng Ye \\ Huazhong Agricultural University College of Resources and Environment \\ Xinwan Zhang \\ Huazhong Agriculture University College of Horticulture and Forestry Sciences \\ Wei Huang \\ Huazhong Agriculture University College of Horticulture and Forestry Sciences \\ Hua Zhao ( $\nabla$ zhaohua@mail.hzau.edu.cn ) \\ Huazhong Agricultural University https://orcid.org/0000-0001-9980-1075 \\ Dejiang Ni \\ Huazhong Agriculture University College of Horticulture and Forestry Sciences}

\section{Research article}

Keywords: tea plant, $\mathrm{N}$ concentration, dynamic change, $\mathrm{N}$ remobilization rate, $\mathrm{N}$ utilization efficiency, genotypic variation

Posted Date: September 23rd, 2019

DOI: https://doi.org/10.21203/rs.2.14710/v1

License: (c) (i) This work is licensed under a Creative Commons Attribution 4.0 International License. Read Full License 


\section{Abstract}

Background: Tea plant ( Camellia sinensis ) is an evergreen perennial plant and characterized by a high nitrogen $(\mathrm{N})$ requirement. There are roundly bud sprouting and leaves development for plucking and pruning annually, leading to continuous and substantial amount of $\mathrm{N}$ removal. Appropriate level of $\mathrm{N}$ application is closely related with high yield and top quality, therefore understanding the underlying mechanism is very crucial for development of optimized tea garden management practices according to genotypes' requirement.

Results: This study aimed to assess variation for dynamic $\mathrm{N}$ concentration, $\mathrm{N}$ remobilization efficiency (NRE) and $\mathrm{N}$ utilization efficiency (NUtE) changes during growing seasons among 20 tea plant cultivars at sufficient $\mathrm{N}$ level. The average $\mathrm{N}$ concentration varied between 31.05 and $44.2 \mathrm{~g} \mathrm{~kg} \mathrm{-1}$ in one bud with two leaves, between 22.67 and $29.42 \mathrm{~g} \mathrm{~kg} \mathrm{-1}$ in leaves attached to green-red stems, between 20.79 and $24.57 \mathrm{~g} \mathrm{~kg}-1$ respectively. The dynamic changes of $\mathrm{N}$ concentration represented different profiles of ' $\mathrm{S}$ ', ' $U$ ' and 'S-like'-shape respectively. Specific NRE defined here is dependent on the development rounds and accompanied with $\mathrm{N}$ fluxes between leaves compartments. Nevertheless, the rates and order of $\mathrm{N}$ remobilization were inconsistent among genotypes during the entire growing seasons, which might be affected by the amount of $\mathrm{N}$ requirement and managed at whole plant level. The dynamic changes of average NUtE among cultivars followed an ' $S$ '-shape. NUtE addressed here was special for harvestable part and lower NUtE is highly associated with tea quality.

Conclusions: The result revealed the annual growing rhythm and physiological character related with $\mathrm{N}$ indices, which was related with the amount and optimal time for $\mathrm{N}$ fertilization requirement dependent on tea plant genotype. An optimized NUtE should be optimized by combination of tea garden management and breeding practices to achieve economic benefit, $\mathrm{N}$ use efficiency and sustainable development.

\section{Background}

Tea plant (Camellia sinensis (L.) O. Kuntze), originated in southwestern part of China, is a perennial evergreen beverage plant. The aerial portion of the tea plant is grown as the type of arbor, semi-arbor and shrub, which is much dependent upon genotypes, cultivation management and external environment, and cultivated tea plants belong to the type of semi-arbor and shrub plants [1]. The fresh young shoots of tea plant are the economic harvest part. The phyllotaxy of leaves on the shoot is alternate. Considering the standards of plucking, leaves position on the shoot is of the greatest importance, one bud for famous green tea or black tea in early spring, one bud with one or two leaves for top quality tea, one bud with three or four leaves for Oolong tea, matured leaves with semi-lignified stems for dark tea etc. Generally, young shoot is roundly plucked several times accordingly during the entire growing seasons and harvested leaves yield is much dependent on tea plant genotypes and tea made [2]. Therefore, tea plant is a unique crop from cultivation to harvesting and has its distinct cropping pattern or system, and breeders worldwide have been focused on developing tea plant varieties with better harvest index $(\mathrm{HI})$ to enrich the tea caterogories [3]. 
Over the past decades, tea plant has become the most widely grown beverage crop worldwide and has been cultivated in more than fifty countries in Asia, Africa, South America, Europe and Oceania. Tea plant cultivation acreage and production have increased continuously in recent years [4]. The gain in productivity has been associated with a 20 -fold increase in the use of chemical nitrogen fertilizer and it is expected to increase at least 3-fold by 2050 [5]. Unreasonable amount of $\mathrm{N}$ application to tea plant are very common in the four major tea production areas in China. Excessive application increases the cost of farming, decreases tea quality and causes soil acidification and consolidation and it is especially serious in green tea production [6], and insufficient application leads to yield and quality reduction, which have received much attention by scientists and government officials. They have collaborated to improve tea plant $\mathrm{N}$ fertilization through formula fertilization by soil testing program $[7,8]$. In addition, severity of soil acidification of tea garden due to over-fertilization in tea garden has gradually become unpalatable question to achieve high yield, accordingly, it is against sustainable development. $\mathrm{N}$ is highly related with tea quality as well as economic benefits. Besides integrated field management techniques, breeding programs took yield and adaptability as the priority targets and have selected genotypes with high tea yield, with extended the growing season, early sprouting, distinguished aroma and taste characters [3]. It was undeniably that improvements in tea garden management and breeding efforts in $\mathrm{HI}$ are largely responsible for the increased harvested tea over the last decades $[3,9]$. Breeding hasn't yet focused on nutrient use efficiency and tea production is now approaching a plateau, and therefore further increases in yield will necessitate an increase in nutrient management.

The $\mathrm{N}$ supplied by soil can't always sustain the high $\mathrm{N}$ demand for next round new bud sprouting and leaves development, so $\mathrm{N}$ previously accumulated in the mature leaves is partly remobilized to support. Additionally, unlike annual crops, tea plant ceases vegetative growth and a portion of $\mathrm{N}$ remobilized from leaves and stems is allocated to the maintained canopy and underground roots in autumn and winter [10]. These are two contrasting patterns resulting $\mathrm{N}$ remobilization from sources to sinks. Developing leaves are dominant $\mathrm{N}$ sinks during growing stage and the maintained canopy and underground roots are $\mathrm{N}$ sinks during autumn and winter seasons in tea, which alternate during cropping system. The $\mathrm{N}$ remobilization is highly affected by nutrient condition in plant [11] and it is essential at the whole plant level due to the fact that underlying mechanisms associated with the nutrient budget allow the redistribution of $\mathrm{N}$ between source organs and sink organs for growth and adaptation [12]. Mechanisms related with $\mathrm{N}$ use efficiency were investigated in many crops, to identify two decisive factors of $\mathrm{N}$ uptake during flowering and biomass allocation efficiency to seeds in winter oilseed-rape [13], to reveal canopy $\mathrm{N}$ and light profile parameters contribute to yield and NUE in rice [14, 15], to announce the UK Genetic Improvement Network project for Wheat [16], to make clear relationship between senescence and yield, quality and NUE in perennial grasses etc $[17,18] . \mathrm{N}$ demand is the maximum of the growth activity-driven demand for crops [19]. As might be expected, $\mathrm{N}$ use involves sophisticated mechanisms for uptake, translocation, assimilation and remobilization across the plant's life cycle [20-23]. Consequently, N use efficient (NUE) genotypes and $\mathrm{N}$ fertilizer requirement has become imperative to optimize the friendly environmental farming [22]. The NUE consist of $\mathrm{N}$ uptake efficiency (NUpE) and $\mathrm{N}$ utilization efficiency (NUtE), N supplies have been effectively optimized for maximum NUE through breeding [22]. 
However, little is known about the NRE and NUE in tea plant. The knowledge regarding N dynamic behavior at the whole tea plant level spanning from $\mathrm{N}$ uptake to remobilization and utilization in source and sink organs is still unknown. Towards insight of these, a better understanding of the processes involved in the elaboration of $\mathrm{N}$ partition and remobilization is required. Reasonable definition for nutrient demand and partitioning is a prerequisite. This is particularly critical comparing cultivars with different adaptability for tea processing. Therefore, it is particularly essential and necessary to make clear genotypic variation and dynamic changes over the entire growing seasons, how these traits contribute to NUE, and how they interact with management practices. $N$ management could increase growth rate during rounds of growth and/or enhance the remobilization of assimilates usually leads to a higher $\mathrm{HI}$.

Concerning the importance in $\mathrm{N}$ management and NUE, the $\mathrm{N}$ dynamic behavior at the whole plant level remains largely unknown and genetic variation among tea plant should be evaluated, and an optimization of $\mathrm{N}$ remobilization efficiency (NRE) is required to improve the NUE. Several practices, such as cultivation, breeding, harvest standard, could substantially enhance growth vigour and maintain or even increase the harvestable leaves, mainly via the enhanced remobilization of pre-stored $\mathrm{N}$-containing compound and improved $\mathrm{HI}$, a variable factor particularly in tea production. In the present study, the dynamic genetic variation of NUE and NRE were evaluated based on N concentration during growing seasons for 20 genotypes of 10-year-old tea plants.

\section{Result}

As for perennial plant, it is difficult to calculate the $\mathrm{N}$ retained in the lignified stem and root system and no account is taken of $\mathrm{N}$ amount for these compartments within tea plant. The $\mathrm{N}$ behavior is monitored for the entire above-ground leaves throughout growth period. $\mathrm{N}$ concentration $\left(\mathrm{g} \mathrm{kg}^{-1} \mathrm{DW}\right)$ was quantified during the growing seasons for the three organs. The different phases of leaves harvest were defined spring tea for the two rounds of April and May, summer tea for the two rounds of July and August, autumn tea for one turn in October, which indicates the rounds of new leaves development. Generally, one bud with two leaves are considered as the harvest part and as sinks for $\mathrm{N}$ accumulation, and then they grew and reached the physiological maturity, being as the leaves attached to the green-red stem at next picking harvest time, whether they serve as sources or sinks depends on $\mathrm{N}$ status of tea plant. The most of leaves attached to the grey stem are usually leaves developed last year. $\mathrm{N}$ concentration determination in a series of 20 tea plant varieties, starting spring tea season in early April and ending autumn tea season in October before pruning, were carried out.

$\mathrm{N}$ repartition within tea plants has not yet been well characterized during each round of new leaves development. All source and sink organs undergo $\mathrm{N}$ remobilization, but the efficiency with which it can be transferred to new developed leaves and the rate of $\mathrm{N}$ remobilization may vary according to the organs. In tea plant, $\mathrm{N}$ remobilization associated with vegetative growth in summer and dormancy in winter is considered as crucial for tea production potential and quality, and also related with NUE. 


\section{Dynamic changes of $\mathrm{N}$ concentration in different leaves during the growing seasons}

$\mathrm{N}$ concentration is correlated to $\mathrm{N}$ availability within plants. The dynamic changes of $\mathrm{N}$ concentration for one bud with two leaves differed between development rounds during the growth period. The $\mathrm{N}$ concentration decreased from first picking round with average of $44.2 \mathrm{~g} \mathrm{~kg}^{-1}$ early in April, to $41.55 \mathrm{~g} \mathrm{~kg}^{-}$

1 in May, to $34.50 \mathrm{~g} \mathrm{~kg}^{-1}$ in July, and a transient increase up to $39.0 \mathrm{~g} \mathrm{~kg}^{-1}$ in August, and then decreased thereafter with the lowest of $31.05 \mathrm{~g} \mathrm{~kg}^{-1}$ in October, being ' $\mathrm{S}$ '-shaped trend (Figure 2a). Natural variation of $\mathrm{N}$ concentration among 20 elite tea plant varieties was indicated by coefficiency variation (CV), $15.16 \%$ (October) $>9.43 \%$ (May) $>8.32 \%$ (April) $>8.07 \%$ (July) $>7.08$ (August) (Table 2), which showed that $\mathrm{N}$ concentration variation is relatively limited in spring season and extensive in autumn season.

The averaged $\mathrm{N}$ concentration for leaves attached to green-red stems decreased from April of $27.99 \mathrm{~g} \mathrm{~kg}^{-}$ ${ }^{1}$ to July of $22.67 \mathrm{~g} \mathrm{~kg}^{-1}$, whereas increased up to $23.62 \mathrm{~g} \mathrm{~kg}^{-1}$ in August and then to $29.42 \mathrm{~g} \mathrm{~kg}^{-1}$ in October, being ' $U$ '-shaped trend (Figure 1b). Genotypic variation of $\mathrm{N}$ concentration among 20 elite tea plant varieties was indicated by $\mathrm{CV}$, presenting relatively high of $13.17 \%$ (April) and $12.32 \%$ (May), followed by $6.08 \%, 6.06 \%$ and $5.65 \%$ in October, July and August respectively (Table 2), which showed different pattern for $\mathrm{N}$ concentration variation among the cultivars, extensive in spring season and limited in autumn season.

Upon to the $\mathrm{N}$ concentration in leaves attached to grey stems, from April to May, first it increased from $20.79 \mathrm{~g} \mathrm{~kg}^{-1}$ to $24.57 \mathrm{~g} \mathrm{~kg}^{-1}$ and reached a peak level, and then decreased to $21.19 \mathrm{~g} \mathrm{~kg}^{-1}$ in July, and remained relatively constant, $21.93 \mathrm{~g} \mathrm{~kg}^{-1}$ and $21.71 \mathrm{~g} \mathrm{~kg}^{-1}$ in August and October respectively, throughout the growing seasons as 'S-like'-shape, suggested reaching a plateau for summer and autumn seasons. Genotypes differed significantly in $\mathrm{N}$ concentration among 20 elite tea plant varieties with $\mathrm{CV}$ of $16.60 \%$ (April) $>16.16 \%$ (May) $>13.60 \%$ (July) $>11.11 \%$ (October) $>8.16 \%$ (August) (Table 2), which showed an obvious descending trend from April to August, and reversely increased from August to October.

\section{Overall comparison pattern of $\mathbf{N}$ concentration in different organs}

Overall, $\mathrm{N}$ concentrations were highest in the compartment of one bud with two leaves followed by leaves attached to green-red stems, and lowest in leaves attached to grey stems during the entire growing seasons. The differences between one bud with two leaves and the leaves attached to green-red stems were particularly obvious during the period of most rapid growth, in spring (April and May) and summer (July and August). Notably, distinctive differences between the leaves attached to green-red and grey stems were observed when tea plants re-grow in early spring (April) and stop growing in autumn (October), whereas there were no obvious differences during the vigorous growing period, from May to August. As mentioned above, $\mathrm{N}$ concentration dynamic changes patterns during the entire growing seasons differed among the three compartments along canopy, and it showed a largest fluctuation in the 
bud with two leaves, followed by the leaves attached to green-red stems, and then by the leaves attached to grey stems.

Interestingly, different compartments exhibited peak $\mathrm{N}$ concentration in the entire growing seasons, it was peaked in May for most of genotypes in the leaves attached to the grey stems according to Figure 2c. For the other two compartments, they exhibited similar patterns over the growing seasons between April and July, from an averagely peak level to a consecutive downward trend. Over the next growing seasons from July to October, these two organs showed distinctive trends, $\mathrm{N}$ concentration first increased gradually and reached a peak level in August and then declined again from August to October for the bud with two leaves, whereas for the leaves attached to green-red stems, there was a weakly rising and stayed a low level for a sustained period from July to August, followed by a substantial increase from August to October (Figure $2 b$ ), which were nearly equal to those in spring. The fluctuation of $\mathrm{N}$ concentration in leaves of the three compartments attached to different vertical position presumably indicated the variation of $\mathrm{N}$ demand concomitant with round by round growth.

\section{Dynamic changes of $\mathbf{N}$ remobilization efficiency in different leaves during the growing seasons}

Within tea plant, $\mathrm{N}$ partitioning is desirable of a maximum $\mathrm{N}$ concentration in harvest part and a minimum $\mathrm{N}$ concentration in the reserves, including canopy-leaves attached to green-red and grey stems, stems and root. The $\mathrm{N}$ dynamic changes of $\mathrm{N}$ concentration allowed us to trace the amount of $\mathrm{N}$ requirement and to determine the $\mathrm{N}$ remobilization and redistribution between the leaves with varied tenderness as the two various compartments. The bud with two leaves is always the newly developed for each round growth and harvest part, thus it is taken for granted meaningless for $\mathrm{N}$ remobilization. Therefore, the $N$ remobilization efficiency (NRE) was defined as NRE $=\left(C_{B}-C_{A}\right) / C_{A}$, and $C_{A} / C_{B}$ is the $N$ concentration of the $A^{\text {th }} / B^{\text {th }}$ round special for the leaves attached to green-red stems or grey stems. Totally four NREs were calculated between the five developed rounds for the two parts of leaves, which are subject to obtain a dynamic view of $\mathrm{N}$ internal remobilization during the growing seasons. NRE is assumed as one of the most responsive traits, as it integrates $\mathrm{N}$ concentration of two consecutive growth rounds into a single trait. The Figure 3 represented an integrated view of the NREs for the two parallels canopy leaves throughout the growing period.

The dynamic changes of NREs were determined for the leaves attached to green-red stems among the 20 tea plant cultivars during growing period (Figure 3a). During the first period between the first two rounds (from April to May), seventeen varieties presented NREs $<0$, ranging between $-33.86 \%$ and $-1.82 \%$. By contrast, other three varieties showed NREs $>0$, being $5.06 \%$ of cv. Shuchazao, $26.39 \%$ of cv.

Fudingdahao and $38.03 \%$ of $\mathrm{cv}$. Mingxuan 131 respectively. During the second period between the $2^{\text {nd }}$ and $3^{\text {rd }}$ round (from May to July), a series of fifteen cultivars were NREs $<0$ and varied between $-29.11 \%$ and $-3.51 \%$, and the remained five cultivars were NREs $>0$, ranging between $1.24 \%$ and $14.30 \%$. Compared with those of the first period, no matter what NREs $<0$ or NREs $>0$, the interval between NREs 
value was markedly reduced in the second period. During the third period between the $3^{\text {rd }}$ and $4^{\text {th }}$ round (from July to August), the result made entirely opposite findings towards the NREs value and there were fifteen cultivars with NREs $>0$ and five cultivars with NREs $<0$. The range for NREs $>0$ was relatively moderate, from $0.19 \%$ to $20.14 \%$. The range for NREs $<0$ was further decreased, from $-10.94 \%$ to $0.63 \%$. During the fourth period between the $4^{\text {th }}$ and $5^{\text {th }}$ round (from August to October), all the cultivars exhibited NREs $<0$ with the obviously extensive range between $-12.21 \%$ and $-51.35 \%$. Such genotype with high NREs does not necessarily reduce harvestable leaves yield even when plants are grown under low $\mathrm{N}$ conditions.

The dynamic changes of NREs were determined for the leaves attached to grey stems among the 20 tea plant cultivars during growing period (Figure 3b). The leaf age is almost one year and approach senescent. During the first period between the first two rounds (from April to May), only six varieties presented NREs $<0$, ranging between $-29.56 \%$ and $-0.15 \%$. By contrast, other fourteen varieties showed NREs $>0$ and ranged between $9.61 \%$ and $102.66 \%$. During the second period between the $2^{\text {nd }}$ and $3^{\text {rd }}$ round (from May to July), totally of fourteen cultivars were NREs $<0$ and varied between $-44.73 \%$ and $4.50 \%$, and the remained six cultivars were NREs $>0$, ranging between $0.64 \%$ and $13.16 \%$. Compared with those of the first period, the interval between NREs value was markedly reduced for NREs $>0$ and increased for NREs $<0$ in the second period. During the third period between the $3^{\text {rd }}$ and $4^{\text {th }}$ round (from July to August), the result showed that thirteen cultivars were NREs $>0$ and seven were NREs $<0$. During the fourth period between the $4^{\text {th }}$ and $5^{\text {th }}$ round (from August to October), twelve cultivars exhibited NREs $<0$ with range between $-1.95 \%$ and $-17.69 \%$, and the range for NREs $>0$ was approximately comparable to that of NREs $<0$.

Theoretically, NRE $<0, N$ was exported from the specific leaves as $N$ source organs during the period of two consecutive rounds, thereby reusing $\mathrm{N}$ within plant to improve the NUE consequently. Conversely, NRE $>0, \mathrm{~N}$ was transported inwardly and the specific leaves acted as $\mathrm{N}$ sink organ to accumulate $\mathrm{N}$. Therefore, the extent of $\mathrm{N}$ remobilization from source to sink/young developed leaves varied significant among tea plant genotypes, which is indicative for $\mathrm{N}$ dynamic behavior within tea plant.

\section{Dynamic changes of $\mathbf{N}$ utilization efficiency (NUtE) during the growing seasons}

The efficiency to $\mathrm{N}$ assimilation and remobilization are involved in NUtE in tea plant. The average NUtE from April to July increased from $22.76 \mathrm{~g} \mathrm{~g}^{-1} \mathrm{~N}$ to $29.05 \mathrm{~g} \mathrm{~g}^{-1} \mathrm{~N}$, and decreased at $25.77 \mathrm{~g} \mathrm{~g}^{-1} \mathrm{Nin}$ August, and then conversely increased up to $32.99 \mathrm{~g} \mathrm{~g}^{-1} \mathrm{~N}$ in October, and the dynamic changes of NUtE followed an ' $\mathrm{S}$ '-shape (Figure 4) which is contrary to that of $\mathrm{N}$ concentration in bud with two leaves. With respect to the roundly harvest for sprouted young bud with two leaves among the tested cultivars, the NUtE ranged between $19.51 \mathrm{~g} \mathrm{~g}^{-1}$ and $26.39 \mathrm{~g} \mathrm{~g}^{-1} \mathrm{~N}$ in April, between $22.70-27.94 \mathrm{~g} \mathrm{~g}^{-1} \mathrm{~N}$ in August, which was in a relatively low and limited range and indicated that $\mathrm{N}$ was in great demand in the young part for harvest. The scopes of NUtE in May and July were $20.44-30.35 \mathrm{~g} \mathrm{~g}^{-1} \mathrm{~N}$ and $24.09-34.15 \mathrm{~g} \mathrm{~g}^{-1} \mathrm{~N}$ 
respectively, which were significantly extended. Particularly in October, $24.53-41.25 \mathrm{~g} \mathrm{~g}^{-1} \mathrm{~N}$, the spectrums were further enlarged, respectively.

At the onset of genotype level, the dynamic changes of NUtE were obviously observed during the growing period and significant variations were found among the tea plant cultivars (Table 1). Interestingly, the ranges of NUtE of five cultivars, cv. Echa10, cv. Huangdan, cv. Shuchazao, cv. Jinxuan and cv. Jiaming 1, were extremely limited, showing very consistent pattern with peak in July and valley in April. By contrast, the two cultivars' NUtE showed a broad range and were nearly two-fold between the maximum in October and minimum in April, 20.54-41.25 $\mathrm{g} \mathrm{g}^{-1} \mathrm{~N}$ for cv. Meizhan and 20.35-38.05 $\mathrm{g} \mathrm{g}^{-1} \mathrm{~N}$ for cv. Yingshuang respectively. For the remaining tea plant varieties, NUtE went upward trend from April to July and reversely went downward between July and August, finally went upward and peaked in October.

\section{Discussion}

One bud with two leaves production is the harvest yield for tea plant cultivation. $\mathrm{N}$ is an essential element existed in most macromolecules and many signaling and secondary compounds, such as caffeine and theanine etc. Caffeine (1,3,7-trimethyl xanthine) is up to $2.80 \%$ in young shoot at dry weight [24] and theanine ( $\mathrm{Y}$-glutamyl-L-ethylamide) is up to $4.53 \%$ in tea leaves [25]. Therefore, $\mathrm{N}$ is the most important nutrient determining tea quality and yield. According to $\mathrm{N}$ concentration in various parts over the growing time, major $\mathrm{N}$ were priority participated to the youngest aboveground part, one bud with two leaves. Relatively lower and constant of $\mathrm{N}$ concentration in the leaves attached to the grey stems suggested their supportive function of photosynthesis, and the amount of $\mathrm{N}$ stored dominates due to the substantial biomass. The leaves of this part most likely contributed a lot to photosynthetic $\mathrm{N}$ use efficiency (PNUE) previously proposed by Brown [26]. Photosynthetic activity and leaves productivity was greatly increased by introducing cyanobacterial Rubisco into tobacco [27]. It remains to be investigated if NUE could be increased by modifying both $\mathrm{N}$ and $\mathrm{C}$ metabolism in parallel in tea plant, though $\mathrm{N}$ assimilation is intrinsically linked to both photosynthetic activity and the overall $\mathrm{C}$ status in a complex and tightly regulated system referred to as the $\mathrm{C}: \mathrm{N}$ balance [28].

In addition, the $\mathrm{N}$ concentration was highest in the youngest developing leaves, and declined as the leaves expands attached to green-red stems, and then declined as the leaves mature to attached to grey stems. Except for the similarity between the upper two compartments in October, the $\mathrm{N}$ concentrations were always approximately 1.5 -fold higher in bud with two leaves than in leaves attached to green-red stem, and between 1.43- and 2.13-fold than in leaves attached to grey stem, which were coincident with the contents of metabolites, especially for caffeine and free amino acids of high nitrogen-containing compounds, and therefore presumably reflected higher metabolic activity in young tissues. Contrarily, relatively low $\mathrm{N}$ concentrations in leaves attached to grey stem were much constant over the entire growing period and probably conserved $\mathrm{N}$ as sources. In the present study, the tea wasn't picked for tea production during the experiment period and the tea plant grew round by round naturally without harvest. The absorbed $\mathrm{N}$ was allocated to all sinks (also including the stem aboveground and roots underground, which were not quantified in this study for the difficulty) to maintain a certain $\mathrm{N}$ concentration range 
without continuous increase consequently. The dynamic change patterns for $\mathrm{N}$ concentration probably are totally different. Furthermore, the patterns of $\mathrm{N}$ demand were indicated by the dynamic changes of $\mathrm{N}$ concentration, at least, the basic principles involved in amount and optimum time of fertilization application were quite explicit for each genotype. Certainly, many haven't yet figured out for the complex of actual production, which are greatly dependent on the tea type production and environment factors.

$\mathrm{N}$ demand is the maximum of the growth activity-driven demand for crops [19]. For basal and topdressing fertilization for tea plantation, farmers always apply fertilizer by surface broadcasting due to increasingly limited labour and inappropriate mechanization for local site conditions. This leads to substaintial amount of $\mathrm{N}$ loss through gaseous $\mathrm{N}$ emissions, soil denitrification and volatilization, surface leaching, which could result in severe environmental hazards [7-8, 29-30]. Additionally, surface application leads to roots surfaced developed and poor resistance to abiotic stresses of water, cold and nutrients etc. In agricultural production, the pattern of one basal in autumn and two topdressing fertilizations during growing seasons is popular in most areas of tea production regardless of demand amount and temporal differences between tea plant varieties. In recent years, farmers are recommended to adopt the technique of formula fertilization by soil testing. Reasonable definition for nutrient demand and partition is a prerequisite. This is particularly critical when comparing cultivars adaptable for different tea types making. $\mathrm{N}$ partitioning is based on a pre-defined maximum harvest $\mathrm{N}$ concentration and a minimum $\mathrm{N}$ concentration in the reserves, which include canopy-leaves attached to green-red and grey stems, stems and root. Though the shortage of leaves yield and derived $\mathrm{N}$ allocation, these results highlighted the crucial role of $\mathrm{N}$ concentration used to indicate $\mathrm{N}$ demand during the growing seasons. So optimized fertilization is of great important to reduce input and increase NUE, and it is both an economically and environmentally highly desirable traits. Somewhat surprisingly, there were obvious regularities in the dynamic changes for $\mathrm{N}$ concentration, which proved the validity and suitability of the sample approach for leaves at the specific developmental stages, especially for investigating seasonal $\mathrm{N}$ demand.

Once the new round buds sprouting and leaves develops, remobilization of $\mathrm{N}$ from the reserves goes to the youngest parts until the $\mathrm{N}$ concentration in the leaves and roots reach their minimum values to meet their requirements. This remobilization is assumed to stimulate senescence of leaves attached to grey stem. If the $\mathrm{N}$ requirements of harvestable leaves are not met due to ineffective $\mathrm{N}$ budget within intrashoot, $\mathrm{N}$ concentration in harvestable leaves declines, which would subsequently lead to a decline in tea quality. Therefore, $\mathrm{N}$ remobilization efficiency is another candidate parameter for $\mathrm{N}$ management. Under current agronomic practices with NUE around $30 \%$, considerable tea yield of $9-10$ tha ${ }^{-1}$ requires an $\mathrm{N}$ input surplus of around $900 \mathrm{~kg} \mathrm{~N} \mathrm{ha}^{-1}$, an depletion of available soil-N by the tea plant and an incomplete retranslocation of $\mathrm{N}$ from reserved parts into the developing and harvest parts are responsible. For economic and ecological considerations, the high crop-specific $\mathrm{N}$ balance surplus has to be reduced without reducing the current yields and quality.

Apparent remobilization of $\mathrm{N}$ in plant organs for transport to the developing parts can be quantified through the decrease in $\mathrm{N}$ contents of these organs by multiplying $\mathrm{N}$ concentration by specific biomass. As expected, $\mathrm{N}$ remobilization occurred both in the two parts leaves attached to green-red and grey stems 
indicated by dynamic $\mathrm{N}$ concentration, though the difficulties and deficient of specific biomass. In a population of 31 switchgrass accessions, it has proved the correlation between $\mathrm{N}$ remobilization efficiency (NRE) and days' interval from heading to harvest, as well a positive linear correlation between days' interval from heading to harvest and $\mathrm{N}$ concentration in senescent tillers harvested in December [17], which indicated the practicability of the formula defined by dynamic changes of $\mathrm{N}$ concentration for $\mathrm{N}$ remobilization calculation in this study. Due to $\mathrm{N}$ remobilization strongly dependent on genotypes [3134], it is particularly critical when comparing cultivars adaptable for different tea types.

The characteristics of major tea plant cultivars response to $\mathrm{N}$, how they are regulated by field management practices and how it contributes to $\mathrm{N}$ use efficiency (NUE) were remain unclear. A promising approach is the breeding and cultivation of $\mathrm{N}$-efficient cultivars, considerable yield under limited $\mathrm{N}$ and potential yield under normal $\mathrm{N}$ conditions, which allows decreasing the $\mathrm{N}$ application necessary to achieve optimum yields and maintain quality $[13,35]$. Plant NUE is a complex trait that is governed by many physiological processes, including $\mathrm{N}$ uptake, assimilation, metabolism, transport, allocation, and remobilization, as well as environmental factors, such as the availability of soil $\mathrm{N}$. However, strategies for crop improvement generally have not integrated PNUE with plant NUE [36, 37]. NUE has been estimated to be low around $33 \%$ for cereals [38]. Increases in NUE have been achieved by breeding, cultivation and genetic improvement approaches by overexpression key genes involved in $\mathrm{N}$ uptake, assimilation and transport [39-42]. Considering success in NUE improvement, exploiting natural variation and quantitative genetic approaches are definitely worth exploring in tea plants.

\section{Conclusions}

We showed the dynamic changes and genotypic variations of $\mathrm{N}$ indices for 20 ten-year-old clonal tea plant cultivars throughout growing seasons, including the $\mathrm{N}$ concentrations in three leaves compartments partitioning, the $\mathrm{N}$ remobilization in the canopy leaves and NUtE in the young bud-leaves. Despite the variation among the cultivars, obvious trend was observed for the dynamic changes of $\mathrm{N}$ concentration, ' $S$ ', 'U' and 'S-like' shape for the three leaves compartments over the entire growing seasons. The result revealed the annual growing rhythm and physiological character related with $\mathrm{N}$ indices, which was related with the amount and optimal time for fertilization dependent on tea plant genotype. For roundly sprouting and growth and leaf use, special definitions for NRE and NUtE were employed in the present study. According to the dynamic NREs value, the extent of $\mathrm{N}$ remobilization from source to sink/young developed leaves varied significant among tea plant genotypes, which is indicative for $\mathrm{N}$ dynamic behavior within tea plant. For highly related with tea quality, NUtE for the harvested leaves never should be the most important, and usually NUE is improved especially under less optimal $\mathrm{N}$ conditions but with loss yield and quality.

Future work should focus on determining nutrient status for soil, nutrient demand for tea plant and management practices attributes that most contribute to the tea production with different tea product, organic tea and conventional pollution-free tea, top-quality and common tea, to achieve sustainable development. 


\section{Methods}

\section{Plant Materials}

The experimental site is located at Huazhong Agricultural University in Wuhan $\left(30^{\circ} 32.87 \rrbracket \mathrm{N}\right.$, $\left.114^{\circ} 25.01 \mathrm{VE}\right)$, China. It is a suitable area with a warm and subtropical climate for tea plantation and belongs to the tea region of south of the Yangtze River, an average annual temperature of $15.8^{\circ} \mathrm{C}-17.5^{\circ} \mathrm{C}$, average annual precipitation of $1269 \mathrm{~mm}$ distributed unevenly and primarily in the summer months from June to August, average annual 270 days frost-free period in the past three decades. There was spray irrigation as a supplement if necessary. Before basal fertilizer application in 2016, the soil were characterized by low pH levels about 4.5, organic matter of $42.65 \mathrm{~g} \mathrm{~kg}^{-1}$, alkali-hydrolyzable $\mathrm{N}$ of 164.83 $\mathrm{mg} \mathrm{kg}^{-1}$, available $\mathrm{P}$ of $68.06 \mathrm{mg} \mathrm{kg}^{-1}$, available $\mathrm{K}$ of $210.36 \mathrm{mg} \mathrm{kg}^{-1}$ in the soil layer from 0 to $20 \mathrm{~cm}$ depths, which indicates high fertility soil for tea plant plantation. Totally, twenty ten-year-old clonal tea plant (Camellia sinensis L.) cultivars (as described in Table 1) were originally cultivated for tea processing with space interval of $30 \mathrm{~cm}$ between individuals and $1.2 \mathrm{~m}$ between rows respectively. Tea plants separated by cultivars were arranged as $25 \mathrm{~m}$ per row. Since 2009 , tea plants were five-year-old and harvestable, and therefore the field has been managed as an integrated annual fertilization practice, once for basal fertilizer in autumn (October-early in November) and twice for topdressing fertilizer (before sprouting early in March and immediately after spring tea harvest) during growing seasons. $\mathrm{N}$ was applied with the ratio of 7:2:1 for the three times at the rate of $600 \mathrm{~kg} \mathrm{~N} \mathrm{ha}^{-1}$, a relatively moderate $\mathrm{N}$ level of local farmer's practice. Phosphorus $\left(\mathrm{as}_{2} \mathrm{O}_{5}\right.$ ) and potassium (as $\mathrm{K}_{2} \mathrm{O}$ with $\mathrm{SO}_{4}{ }^{2}$ type) were applied with ratio of $\mathrm{N}: \mathrm{P}_{2} \mathrm{O}_{5}: \mathrm{K}_{2} \mathrm{O}=2: 1: 1$ as basal fertilizer in each autumn. Insects, diseases and weeds around the tea garden were controlled by chemical or manual methods to assure tea plant growth and yield loss if possible. These suggested that tea plants grew in high nutrient concentrations with standardized conditions.

\section{Sampling and $\mathbf{N}$ concentration measurements}

Tea plants on the end of each row were not sampled to avoid border effects. Tea plants have multiple branches at different developmental stages due to the pruning practice of last year. The leaves attached to different stems vary in physiologically age and function for their physiological status. To highlight the biological significance and avoid sample bias by collecting a small part of a specific organ, the samples were separated into three parts along vertical canopy layer, one bud with two leaves (youngest), leaves attached to green-red stems (developed and matured leaves) and leaves attached to grey stems (aging leaves), from early in April to middle in October in 2017 (Figure 1). For each cultivar, the samples were sampled with specific position and development stage from 30 individuals and then pooled to avoid sample bias.

The samples were treated at $120^{\circ} \mathrm{C}$ for 10 minutes first and then dried at $65^{\circ} \mathrm{C}$ to constant weight before being ground to a uniform fine powder by a plant mill. The digestion for samples and $\mathrm{N}$ concentration 


\section{Calculation for $\mathbf{N}$ remobilization efficiency (NRE) and $\mathbf{N}$ utilization efficiency (NUtE)}

In tea plant, the $\mathrm{N}$ remobilization associated with vegetative growth in summer and dormancy in winter is considered as crucial for tea production potential and quality, and conversely related with NUE. To estimate $\mathrm{N}$ remobilization efficiencies in the three distinctive organs during the entire growing seasons, the $\mathrm{N}$ concentrations were compared and indicated by $\mathrm{N}$ remobilization efficiency; which was calculated $\mathrm{N}$ concentration difference between the $\mathrm{B}^{\text {th }}$ and $\mathrm{A}^{\text {th }}$ round divided by that of the $\mathrm{A}^{\text {th }}$ round with the formula as follows, NRE $=\left(N\right.$ concentration of $B^{\text {th }}$ round $-N$ concentration of $A^{\text {th }}$ round $) / N$ concentration of $A^{\text {th }}$ round.

$\mathrm{N}$ use efficiency (NUE) is an extremely complex trait and can be divided into two components of $\mathrm{N}$-uptake efficiency (NUpE) and N-utilization efficiency (NUtE). Many definitions of NUE were summarized $[5,22]$ and were applied to implicate indices related with $\mathrm{N}$ budget. In the case of perennial plant, rounds harvest for leaf use and inconsistent harvest index $(\mathrm{HI})$, the definition for NUE is very difficult. It is required to definite a specific NUE to be appropriate for the tea plant germplasm employed. As mentioned above, NUtE is the leaves yield based on $\mathrm{N}$ content involved, and is therefore considered as a preference to optimally characterize $\mathrm{N}$ efficiency specific for tea plant, additionally, overall NUtE will be an integration of all rounds harvested throughout growth periods within a year. Therefore, NUtE is the reciprocal of the N concentration in the harvest part.

\section{Data analysis}

Analysis of variance was performed using SPSS statistical analysis package (version 17.0). Measurement data were compared with LSD (Least Significant Difference test) $(P<0.05)$ and SNK (Student-Newman-Keuls) methods of analysis of variance. Means were tested by least significant difference, and LSD and SNK were employed.

\section{Abbreviations}

NUE: nitrogen use efficient; NUtE: nitrogen utilization efficiency; NRE: nitrogen recombilization efficiency; $\mathrm{N}$ : nitrogen.

\section{Declarations}

\section{Ethics approval and consent to participate}




\section{Consent for publication}

Not applicable presently.

\section{Availability of data and materials}

All the data supporting our findings are contained within the manuscript.

\section{Competing interest}

The authors declare that they have no competing interests.

\section{Funding}

This work was jointly supported by the National Key Research \& Development Program of China (2018YFD1000600), the Fundamental Research Funds for the Central Universities of China (2662018JC046) and National Natural Science Foundation of China (31470406). The funder had no role in the design, determination and interpretation of data and in writing the manuscript.

\section{Authors' contributions}

$\mathrm{HZ}$ and $\mathrm{DN}$ conceived and designed the experiments. $\mathrm{YZ}, \mathrm{XY}, \mathrm{XZ}$ and $\mathrm{WH}$ carried out the experiments and raw data determination. $\mathrm{YZ}$ and $\mathrm{HZ}$ analyzed the data. $\mathrm{HZ}$ wrote the manuscript. All authors read and approved the final manuscript.

\section{Acknowledgements}

We thank Prof. Xiaokun Li for valuable discussions and comments.

\section{References}

1. Yu FL. Discussion on the originating place and the originating center of tea plant. J tea sci. (Chinese), 1986; 01.

2. Luo YP (2015) The cultivation of tea plant. China Agriculture Press, Beijing.

3. Chen L, Apostolides Z, Chen ZM. Global Tea Breeding, Achievements, Challenges and Perspectives. Springer. 2012. 
4. FAOSTAT. FAO Statistical Databases. Food and Agriculture Organization (FAO) of the United Nations, Rome http://www.fao.org/2016.

5. Good AG, Shrawat AK, Muench DG. Can less yield more? Is reducing nutrient input into the environment compatible with maintaining crop production? Trends in Plant Sci. 2004; 9: 597-605.

6. Ruan J, Härdter R, Gerendás J. Impact of nitrogen supply on carbon/nitrogen allocation: a case study on amino acids and catechins in green tea (Camellia sinensis (L.) O. Kuntze) plants. Plant Biol. 2010; 12: $724-734$.

7. Chen XP, Cui ZL, Fan MS, Vitousek P et al. Producing more grain with lower environmental costs. Nature. 2014; 514: 486-491.

8. Zhang F, Chen X, Vitousek P. Chinese agriculture: an experiment for the world. Nature. 2013; 497: 3335.

9. Ruan JY and Gerendás J. Absorption of foliar-applied urea-15N and the impact of low nitrogen, potassium, magnesium and sulfur nutritional status in tea (Camellia sinensis L.) plants. Soil Sci Plant Nutr. 2015; 61: 653-666.

10. Okano K, Komaki S, Matsuo K. Remobilization of nitrogen from vegetative parts to sprouting shoots of young tea (Camellia sinensis L.) plants. Japan J Crop Sci. 1994; 63: 125-130.

11. Maillard A, Etienne P, Diquélou S, Trouverie J, Billard V, Yvin JC, Ourry A. Nutrient deficiencies modify the ionomic composition of plant tissues: a focus on cross-talk between molybdenum and other nutrients in Brassica napus. J Exp Bot. 2016; 67: 5631-5641.

12. Tegeder $M$ and Masclaux-Daubresse $C$. Source and sink mechanisms of nitrogen transport and use. New Phytol. 2018; 217: 35-53.

13. Koeslin-Findeklee F, Horst WJ. Contribution of nitrogen uptake and retranslocation during reproductive growth to the nitrogen efficiency of winter oilseed-rape cultivars (Brassica napus L.) differing in leaf senescence. Agronomy. 2016; 6: 1.

14. Gu JF, Chen Y, Zhang H, Li ZK, Zhou Q et al. Canopy light and nitrogen distributions are related to grain yield and nitrogen use efficiency in rice. Field Crops Res. 2017; 206: 74-85.

15. Li H, Hu B and Chu CC. Nitrogen use efficiency in crops: lessons from Arabidopsis and rice. J Exp Bot. 2017; 68: 2477-2488.

16. Hawkesford MJ. Genetic variation in traits for nitrogen use efficiency in wheat. J Exp Bot. 2017; 68: 2627-2632.

17. Yang JD, Udvardi M. Senescence and nitrogen use efficiency in perennial grasses for forage and biofuel production. J Exp Bot. 2018; 69: 855-865.

18. Yang JD, Worley E, Ma Q, Li J, Torres-Jerez I, Li GY et al. Nitrogen remobilization and conservation, and underlying senescence-associated gene expression in the perennial switchgrass Panicum virgatum New Phytol. 2016; 211: 75-89.

19. Gu JF, Yin XY, Stomph TJ, Struik PC. Can exploiting natural genetic variation in leaf photosynthesis contribute to increasing rice productivity? A simulation analysis. Plant Cell Environ. 2014; 37: 22-34. 
20. Chardon F, Barthélémy J, Daniel-Vedele F, Masclaux-Daubresse C. Natural variation of nitrate uptake and nitrogen use efficiency in Arabidopsis thaliana cultivated with limiting and ample nitrogen supply. J Exp Bot. 2010; 61: 2293-2302.

21. Chardon F, Noël V, Masclaux-Daubresse C. Exploring NUE in crops and in Arabidopsis ideotypes to improve yield and seed quality. J Exp Bot. 2012; 63: 3401-3412.

22. Xu G, Fan X, Miller AJ. Plant nitrogen assimilation and use efficiency. Annu Rev Plant Physiol. 2012; 63: $153-182$.

23. Krapp A. Plant nitrogen assimilation and its regulation: a complex puzzle with missing pieces. Curr Opin Plant Biol. 2015; 25:115-122.

24. Ashihara $\mathrm{H}$, Crozier A. Caffeine: a well known but little mentioned compound in plant science. Trends Plant Sci. 2001; 6(9): 407-413.

25. Lu M, Han J, Zhu B, Jia H, Yang T, Wang R, Deng WW, Zhang ZZ. Significantly increased amino acid accumulation in a novel albino branch of the tea plant (Camellia sinensis). Planta. 2019; 249: 363376.

26. Brown RH. A difference in $\mathrm{N}$ use efficiency in $\mathrm{C} 3$ and $\mathrm{C} 4$ plants and its implications in adaptation and evolution. Crop Sci. 1978; 18: 93-99.

27. Lin MT, Occhialini A, Andralojc PJ, Parry MA, Hanson MR. A faster Rubisco with potential to increase photosynthesis in crops. Nature. 2014; 513:547-550.

28. Nunes-Nesi A, Fernie AR, Stitt M. Metabolic and signaling aspects underpinning the regulation of plant carbon nitrogen interactions. Mol Plant. 2010; 3:973-996.

29. Oh K, Kato T, Li ZP, Li FY. Environmental problems from tea cultivation in Japan and a control measure using calcium cyanamide. Pedosphere. 2006; 16: 770-777.

30. Kamau DM, Spiertz JHJ, Oenema 0, Owuor PO. Productivity and nitrogen use of tea plantations in relation to age and genotype. Field Crops Res. 2008; 108: 60-70.

31. Kichey T, Hirel B, Heumez E, Dubois F, Le Gouis J. In winter wheat (Triticum aestivum L.), postanthesis nitrogen uptake and remobilisation to the grain correlates with agronomic traits and nitrogen physiological markers. Field Crops Res. 2007;102: 22-32.

32. Robertson GP and Vitousek PM. Nitrogen in agriculture: balancing the cost of an essential resource. Annu Rev Environ Resour. 2009; 34: 97-125.

33. Girondé A, Etienne P, Trouverie J, Bouchereau A, Le Cahérec $F$ et al The contrasting $N$ management of two oilseed rape genotypes reveals the mechanisms of proteolysis associated with leaf $\mathrm{N}$ remobilization and the respective contributions of leaves and stems to $\mathrm{N}$ storage and remobilization during seed filling. BMC Plant Biol. 2015a;15:59.

34. Girondé A, Poret M, Etienne P, Trouverie J, Bouchereau A et al. A profiling approach of the natural variability of foliar $\mathrm{N}$ remobilization at the rosette stage gives clues to understand the limiting processes involved in the low $\mathrm{N}$ use efficiency of winter oilseed rape. J Exp Bot. 2015b; 66: 24612473. 
35. Sylvester-Bradley R, Kindred DR. Analyzing nitrogen responses of cereals to prioritize routes to the improvement of nitrogen use efficiency. J Exp Bot. 2009; 60: 1939-1951.

36. Hirel B, Le Gouis J, Ney B, Gallais A. The challenge of improving nitrogen use efficiency in crop plants: towards a more central role for genetic variability and quantitative genetics within integrated approaches. J Exp Bot. 2007; 58: 2369-2387.

37. Kant S, Seneweera S, Rodin J, Materne M, Burch D, Rothstein SJ, Spangenberg G. Improving yield potential in crops under elevated $\mathrm{CO} 2$ : Integrating the photosynthetic and nitrogen utilization efficiencies. Front Plant Sci. 2012; 3:162.

38. Raun WR and Johnson GV. Improving nitrogen use efficiency for cereal production. Agron J. 1999; 91: 357-363.

39. Schofield RA, Bi YM, Kant S, Rothstein SJ. Over-expression of STP13, a hexose transporter, improves plant growth and nitrogen use in Arabidopsis thaliana seedlings. Plant Cell Environ. 2009; 32: 271285.

40. Klemens PA, Patzke K, Deitmer J, Spinner L, Le Hir R, Bellini C, Bedu M, Chardon F, Krapp A, Neuhaus HE. Overexpression of the vacuolar sugar carrier AtSWEET16 modifies germination, growth, and stress tolerance in Arabidopsis. Plant Physiol. 2013; 163:1338-1352.

41. Yanagisawa S, Akiyama A, Kisaka H, Uchimiya H, Miwa T. Metabolic engineering with Dof1 transcription factor in plants: Improved nitrogen assimilation and growth under low-nitrogen conditions. Proc Natl Acad Sci USA. 2004; 101: 7833-7838.

42. Perchlik $M$ and Tegeder $M$. Leaf amino acid supply affects photosynthetic and plant nitrogen use efficiency under nitrogen stress. Plant Physiol. 2018; 178: 174-188.

43. Yu L, Ding GD, Huai ZX, Zhao H. Natural variation of biomass yield and nutrient dynamics in Miscanthus. Field Crops Res. 2013; 151: 1-8.

\section{Tables}

Table 1 The background information for the cultivars for traits determination related with nitrogen. 


\begin{tabular}{|c|c|c|c|c|c|}
\hline codes & Cultivars & $\begin{array}{l}\text { Breeding } \\
\text { strategy }\end{array}$ & Genetic background & $\begin{array}{l}\text { Time for } \\
\text { first } \\
\text { harvest }\end{array}$ & $\begin{array}{c}\text { Processing } \\
\text { suitability for tea } \\
\text { categories }\end{array}$ \\
\hline 1 & Duokangxiang & $\begin{array}{l}\text { pedigree } \\
\text { selection } \\
\text { breeding }\end{array}$ & $\begin{array}{c}\text { Selection from landraces } \\
\text { population, Yuexi county, Anhui } \\
\text { province }\end{array}$ & $\begin{array}{l}\text { Early in } \\
\text { April }\end{array}$ & Green tea \\
\hline 2 & Echa 10 & $\begin{array}{l}\text { Pedigree } \\
\text { selection } \\
\text { breeding }\end{array}$ & Selection from Taizicha population & $\begin{array}{l}\text { Early in } \\
\text { April }\end{array}$ & Green tea \\
\hline 3 & Fuandabai & $\begin{array}{l}\text { Pedigree } \\
\text { selection } \\
\text { breeding }\end{array}$ & $\begin{array}{l}\text { Selection from Fuandabai } \\
\text { population }\end{array}$ & $\begin{array}{l}\text { Late in } \\
\text { March/ } \\
\text { Early in } \\
\text { April }\end{array}$ & $\begin{array}{l}\text { Green/Black/White } \\
\text { tea }\end{array}$ \\
\hline 4 & Fudingdabai & $\begin{array}{l}\text { Pedigree } \\
\text { selection } \\
\text { breeding }\end{array}$ & $\begin{array}{l}\text { Selection from Fuding Dabaicha } \\
\text { population }\end{array}$ & $\begin{array}{l}\text { Late in } \\
\text { March/ } \\
\text { Early in } \\
\text { April }\end{array}$ & $\begin{array}{l}\text { Green/Black/White } \\
\text { tea }\end{array}$ \\
\hline 5 & Fudingdahao & $\begin{array}{l}\text { Pedigree } \\
\text { selection } \\
\text { breeding }\end{array}$ & $\begin{array}{l}\text { Selection from landraces of Fuding } \\
\text { population, Fuding county, Fujian } \\
\text { province }\end{array}$ & $\begin{array}{l}\text { Late in } \\
\text { March/ } \\
\text { Early in } \\
\text { April }\end{array}$ & $\begin{array}{l}\text { Green/Black/White } \\
\text { tea }\end{array}$ \\
\hline 6 & Fuyun 6 & $\begin{array}{l}\text { Cross } \\
\text { breeding }\end{array}$ & cv. Fudingdabai $\square \times$ cv. Yunnandaye $\square$ & $\begin{array}{l}\text { Late in } \\
\text { March }\end{array}$ & $\begin{array}{l}\text { Green/Black/White } \\
\text { tea }\end{array}$ \\
\hline 7 & Huangdan & $\begin{array}{l}\text { Pedigree } \\
\text { selection } \\
\text { breeding }\end{array}$ & Selection from local population & $\begin{array}{l}\text { Late in } \\
\text { March }\end{array}$ & $\begin{array}{l}\text { Oolong/Green/Black } \\
\text { tea }\end{array}$ \\
\hline 8 & Jinguanyin & $\begin{array}{l}\text { Cross } \\
\text { breeding }\end{array}$ & cv. Tie guanyin $\square \times$ cv. Huangdan $\square$ & $\begin{array}{l}\text { Late in } \\
\text { March }\end{array}$ & Oolong/Green tea \\
\hline 9 & Jinmudan & $\begin{array}{l}\text { Cross } \\
\text { breeding }\end{array}$ & cv. Tie guanyin $\llbracket \times$ cv. Huangdan $\square$ & $\begin{array}{l}\text { Late in } \\
\text { March }\end{array}$ & $\begin{array}{l}\text { Oolong/Green/Black } \\
\text { tea }\end{array}$ \\
\hline 10 & Meizhan & $\begin{array}{l}\text { Pedigree } \\
\text { selection } \\
\text { breeding }\end{array}$ & Selection from Meizhan population & $\begin{array}{l}\text { Late in } \\
\text { March/ } \\
\text { Early in } \\
\text { April }\end{array}$ & $\begin{array}{l}\text { Oolong/Green/Black } \\
\text { tea }\end{array}$ \\
\hline 11 & Mingxuan131 & $\begin{array}{l}\text { Pedigree } \\
\text { selection } \\
\text { breeding }\end{array}$ & $\begin{array}{l}\text { Selection from Mingshan } \\
\text { population }\end{array}$ & $\begin{array}{l}\text { Middle in } \\
\text { March }\end{array}$ & Green tea \\
\hline 12 & Qianmei 502 & $\begin{array}{l}\text { Cross } \\
\text { breeding }\end{array}$ & $\begin{array}{c}\text { cv. Fengqing dayecha } \square \times \text { cv. } \\
\text { Xuan'en Changye } \square\end{array}$ & $\begin{array}{l}\text { Early in } \\
\text { April }\end{array}$ & Black tea \\
\hline 13 & Shuchazao & $\begin{array}{l}\text { Pedigree } \\
\text { selection } \\
\text { breeding }\end{array}$ & $\begin{array}{l}\text { Selection from landraces } \\
\text { population, Shucheng county, } \\
\text { Anhui province }\end{array}$ & $\begin{array}{l}\text { Early in } \\
\text { April }\end{array}$ & Green tea \\
\hline 14 & Jinxuan & $\begin{array}{l}\text { Cross } \\
\text { breeding }\end{array}$ & cv. Tainong $8 \llbracket \times$ cv. Yingzhihongxin $\square$ & $\begin{array}{l}\text { Early in } \\
\text { April }\end{array}$ & Oolong tea \\
\hline 15 & Tieguanyin & $\begin{array}{l}\text { Pedigree } \\
\text { selection } \\
\text { breeding }\end{array}$ & $\begin{array}{l}\text { Core parent for oolong tea, } \\
\text { selected from Anxi county, Fujian } \\
\text { province }\end{array}$ & $\begin{array}{l}\text { Late in } \\
\text { March }\end{array}$ & Oolong/Green tea \\
\hline 16 & Jiaming 1 & $\begin{array}{l}\text { Pedigree } \\
\text { selection } \\
\text { breeding }\end{array}$ & $\begin{array}{l}\text { Selection from Wuniuzao } \\
\text { population }\end{array}$ & $\begin{array}{l}\text { Early in } \\
\text { April }\end{array}$ & Green tea \\
\hline 17 & Yingshuang & $\begin{array}{l}\text { Cross } \\
\text { breeding }\end{array}$ & cv. Fudingdabai $\square \times$ cv. Yunnandaye [ & $\begin{array}{l}\text { Early in } \\
\text { April }\end{array}$ & Green/Black tea \\
\hline 18 & Zhongcha 102 & $\begin{array}{l}\text { Pedigree } \\
\text { selection } \\
\text { breeding }\end{array}$ & Selection from Longjing population & $\begin{array}{l}\text { Early in } \\
\text { April }\end{array}$ & Green tea \\
\hline 19 & Zhongcha 108 & $\begin{array}{l}\text { Mutation } \\
\text { breeding }\end{array}$ & $\begin{array}{l}\text { Radiation mutation pedigree from } \\
\text { cv. Longjing } 43\end{array}$ & $\begin{array}{l}\text { Early in } \\
\text { April }\end{array}$ & Green tea \\
\hline 20 & Zimudan & $\begin{array}{l}\text { Pedigree } \\
\text { selection }\end{array}$ & $\begin{array}{l}\text { An hybrid line selected from } \\
\text { natural crossing with cv. Tie }\end{array}$ & $\begin{array}{l}\text { Late in } \\
\text { March }\end{array}$ & Oolong tea \\
\hline
\end{tabular}


Table 2 Summary for $\mathrm{N}$ concentrations $\left(\mathrm{g} \mathrm{kg}^{-1}\right)$ in the three compartments of leaves over the entire growing seasons.

\begin{tabular}{|c|c|c|c|c|c|}
\hline & April & May & July & August & October \\
\hline & \multicolumn{5}{|c|}{$\mathrm{N}$ concentration in one bud with two leaves $\left(\mathrm{g} \mathrm{kg}^{-1}\right)$} \\
\hline Maximun & $51.25 \pm 0.64$ & $48.98 \pm 0.17$ & $41.52 \pm 0.39$ & $44.12 \pm 0.10$ & $40.78 \pm 1.10$ \\
\hline Minimun & $37.90 \pm 0.79$ & $32.97 \pm 0.25$ & $29.32 \pm 1.36$ & $35.79 \pm 0.86$ & $24.24 \pm 0.50$ \\
\hline Mean & 44.2 & 41.55 & 34.50 & 39.0 & 31.05 \\
\hline Standard Deviation (SD) & 3.68 & 3.91 & 2.78 & 2.70 & 4.70 \\
\hline \multirow[t]{2}{*}{ Coefficient of Variation (CV, \%) } & $8.32 \%$ & $9.43 \%$ & $8.07 \%$ & $7.08 \%$ & $15.16 \%$ \\
\hline & \multicolumn{5}{|c|}{$\mathrm{N}$ concentration in leaves attached to green-red stems $\left(\mathrm{g} \mathrm{kg}^{-1}\right)$} \\
\hline Maximun & $32.65 \pm 2.24$ & $30.06 \pm 0.67$ & $25.02 \pm 1.69$ & $26.37 \pm 1.18$ & $34.80 \pm 0.09$ \\
\hline Minimun & $17.32 \pm 1.13$ & $18.64 \pm 0.52$ & $19.31 \pm 0.96$ & $19.31 \pm 0.11$ & $26.83 \pm 0.62$ \\
\hline Mean & 27.99 & 25.47 & 22.67 & 23.62 & 29.42 \\
\hline Standard Deviation (SD) & 3.68 & 3.13 & 1.37 & 1.33 & 1.79 \\
\hline \multirow[t]{2}{*}{ Coefficient of Variation (CV, \%) } & $13.17 \%$ & $12.32 \%$ & $6.06 \%$ & $5.65 \%$ & $6.08 \%$ \\
\hline & \multicolumn{5}{|c|}{$\mathrm{N}$ concentration in leaves attached to grey stems $\left(\mathrm{g} \mathrm{kg}^{-1}\right)$} \\
\hline Maximun & $30.46 \pm 0.27$ & $29.08 \pm 0.27$ & $25.23 \pm 0.31$ & $24.65 \pm 0.28$ & $26.94 \pm 1.46$ \\
\hline Minimun & $13.76 \pm 1.70$ & $16.93 \pm 0.39$ & $15.75 \pm 0.20$ & $18.47 \pm 0.14$ & $17.12 \pm 0.62$ \\
\hline Mean & 20.79 & 24.57 & 21.19 & 21.93 & 21.71 \\
\hline Standard Deviation (SD) & 3.45 & 3.97 & 2.88 & 1.79 & 2.41 \\
\hline Coefficient of Variation (CV, \%) & $16.60 \%$ & $16.16 \%$ & $13.60 \%$ & $8.16 \%$ & $11.11 \%$ \\
\hline
\end{tabular}

Figures 


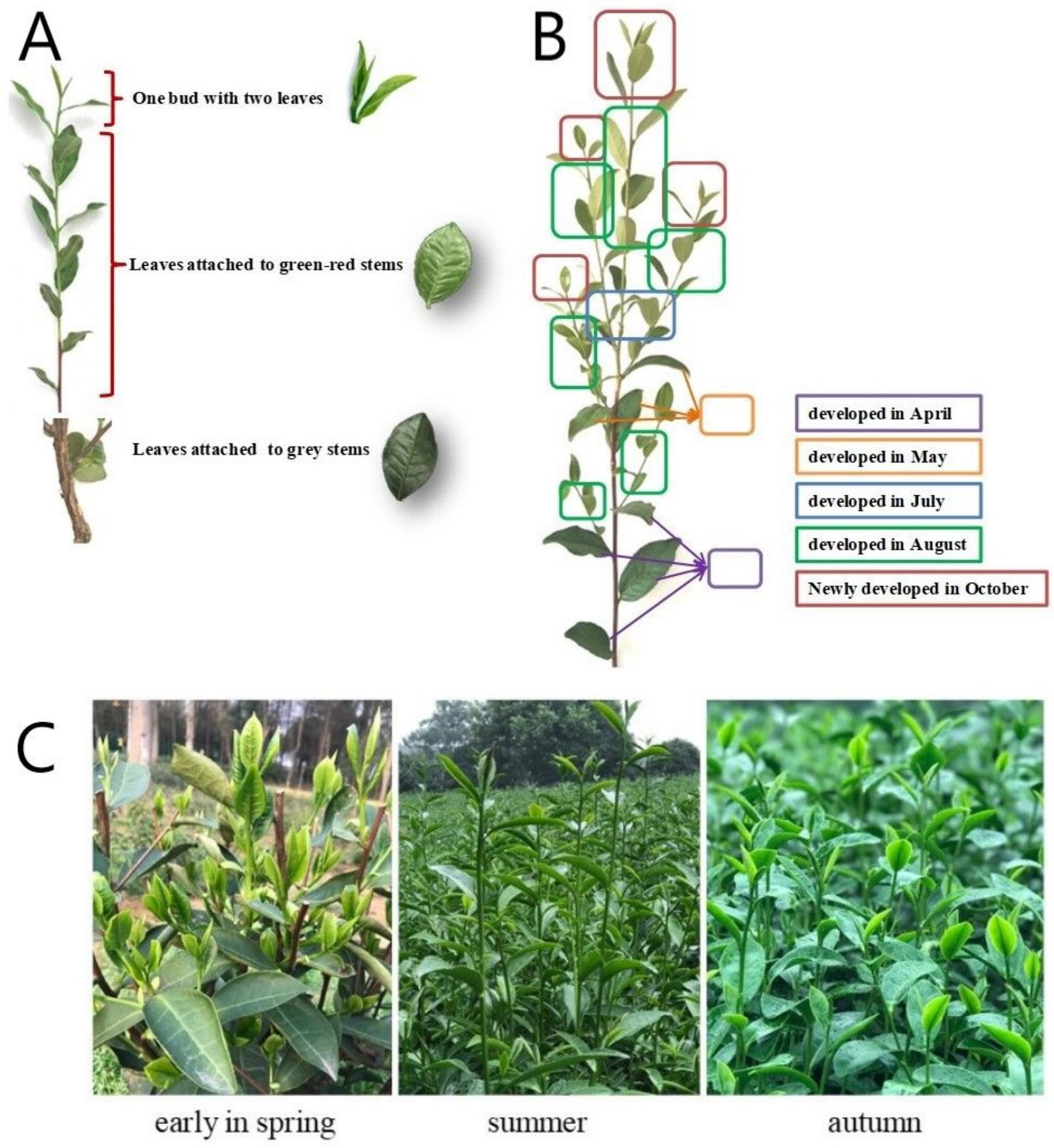

\section{Figure 1}

Diagram for tea plant sample standard (a); rounds development of leaves on the tea plant phyllotaxy (b);.growth performance in tea garden over the entire seasons, in early spring, summer and autumn respectively (c). 

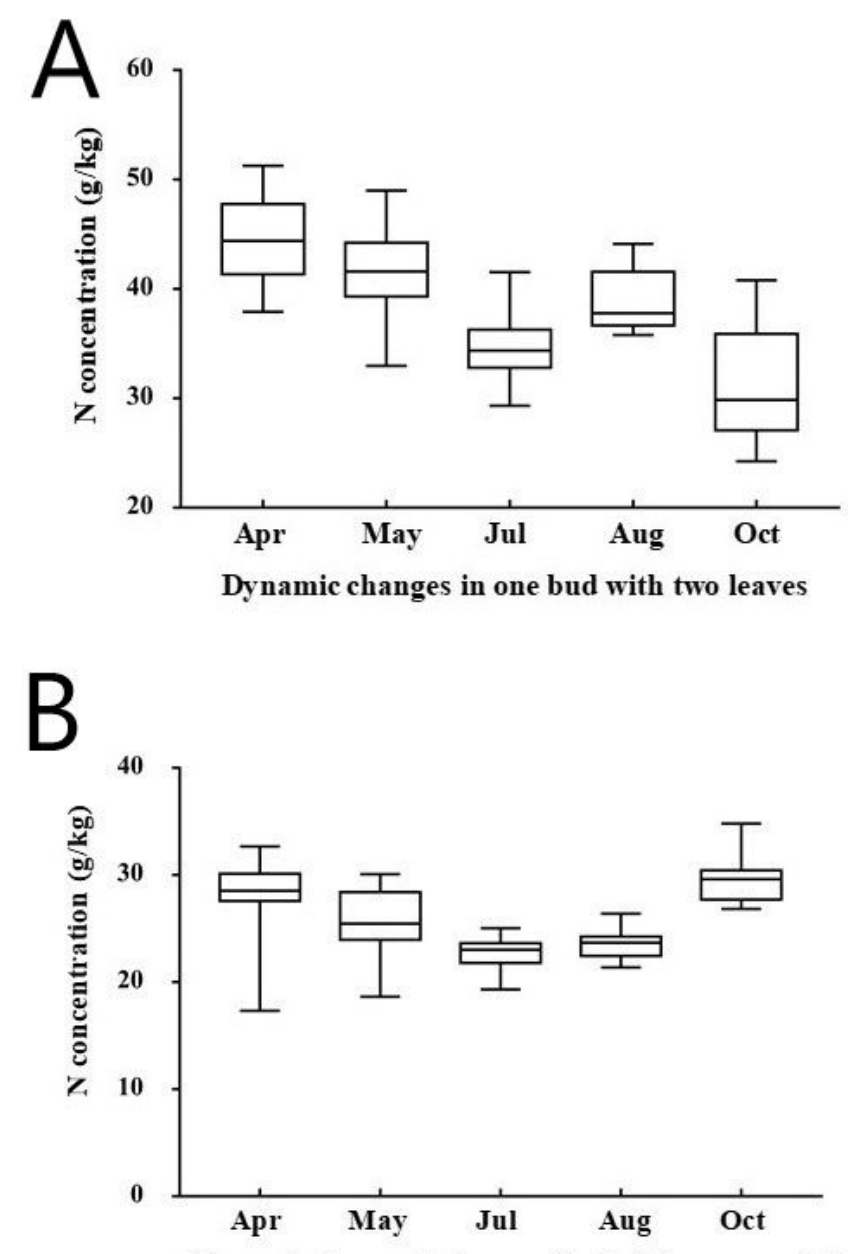

Dynamic changes in leaves attached to green-red stems

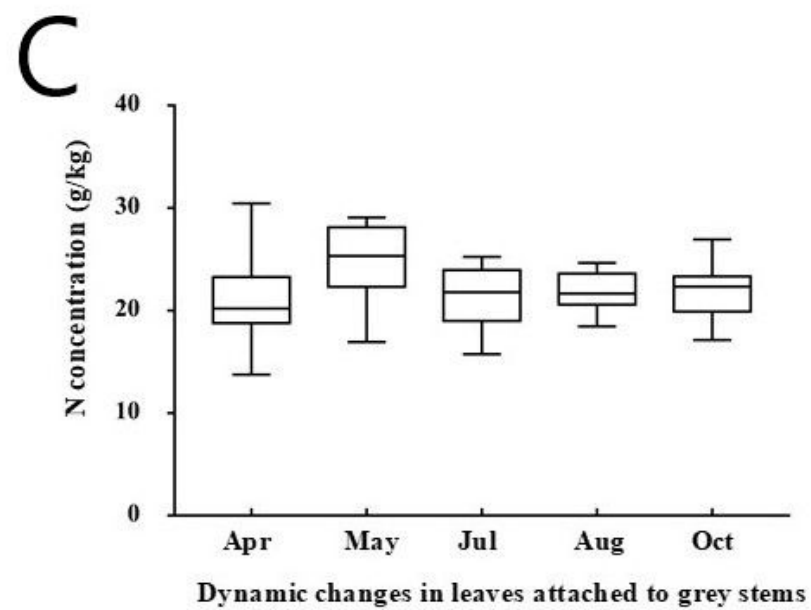

Figure 2

Boxplots for dynamic changes of $\mathrm{N}$ concentration ( $\mathrm{g} \mathrm{N} \mathrm{kg-1} \mathrm{DW)} \mathrm{in} \mathrm{the} \mathrm{three} \mathrm{comparments} \mathrm{of} \mathrm{leaves,} \mathrm{one}$ bud with two leaves (a), leaves attached to green-red stems (b) and grey stems during the growing seasons. 


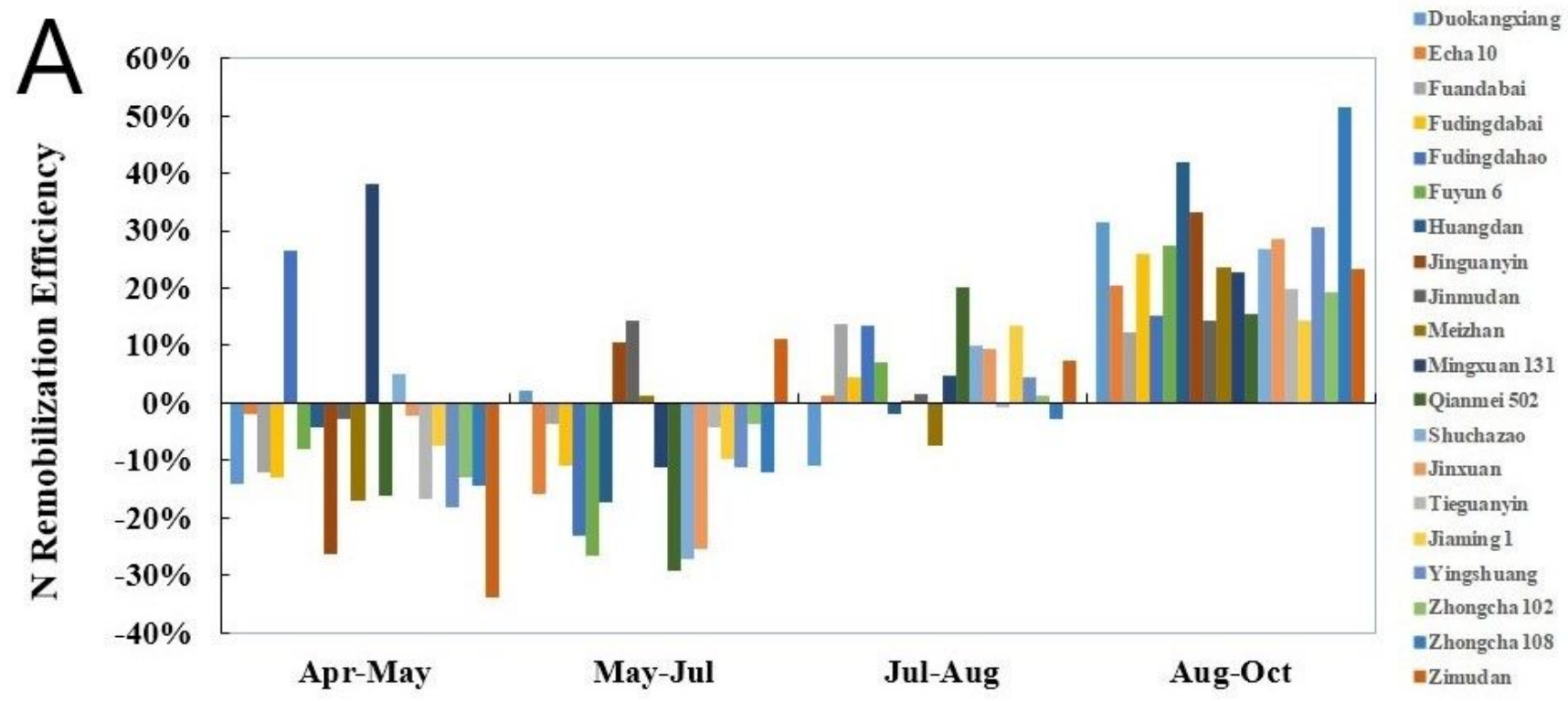

Dynamic changes in leaves attached to green-red stems between rounds

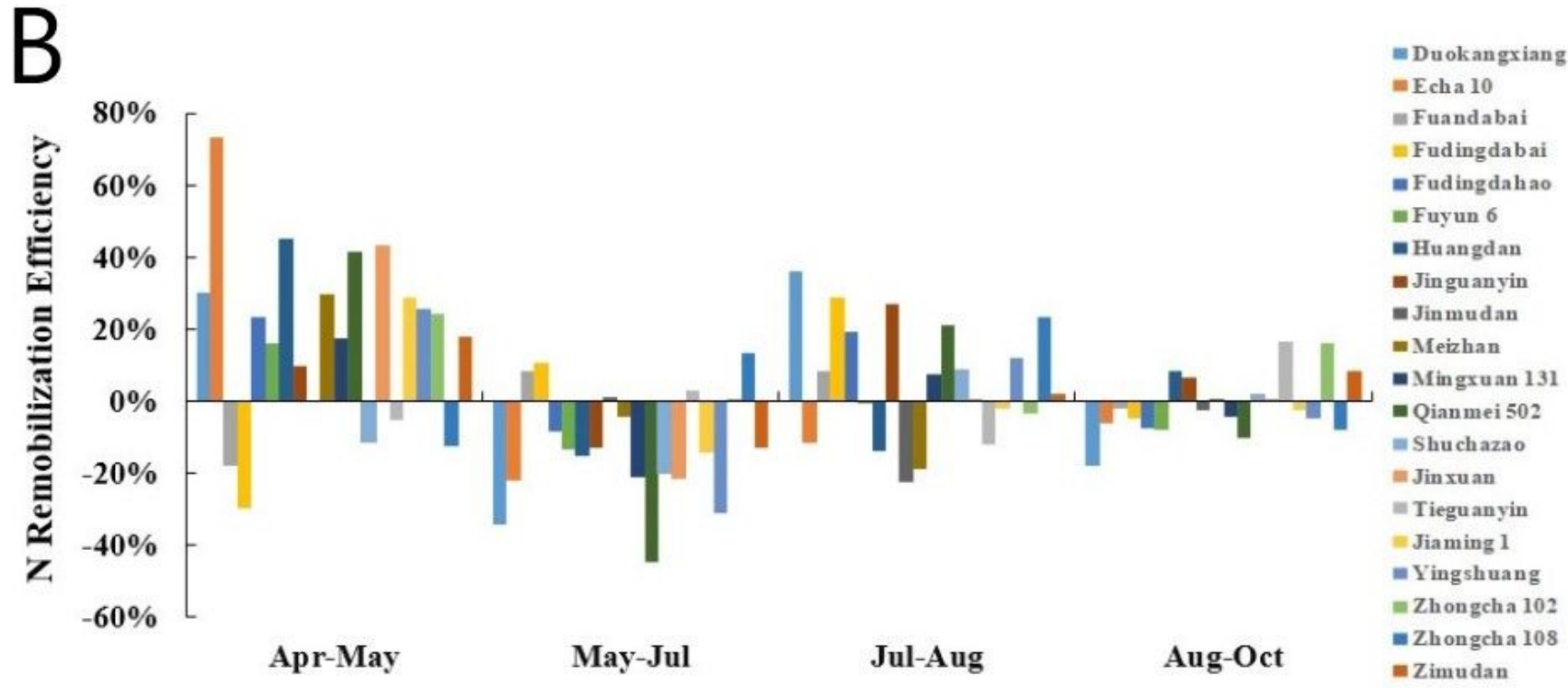

Dynamic changes in the leaves attached to grey stems between rounds

\section{Figure 3}

Dynamic changes of $\mathrm{N}$ utilization efficiency for leaves attached to green-red (a) and grey stems (b) during the growing seasons. 


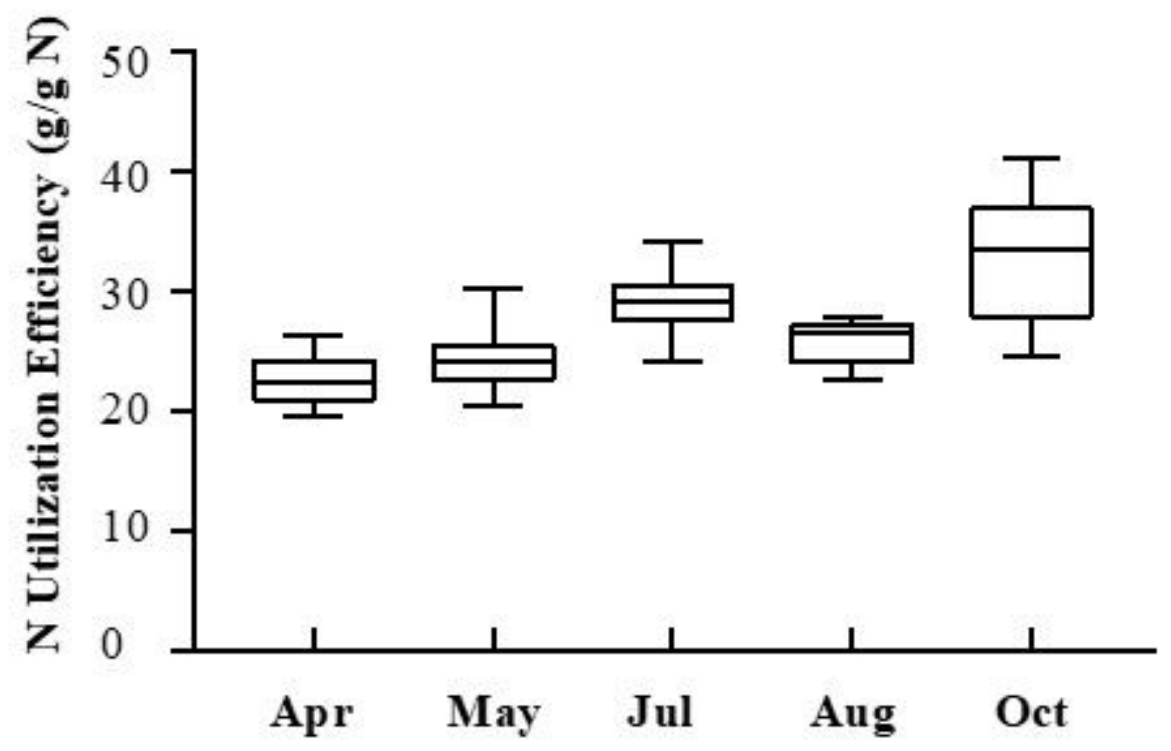

Dynamic changes in the one bud with two leaves

\section{Figure 4}

Boxplot for dynamic changes of $\mathrm{N}$ utilization efficiency (NUtE, g g-1 N) for the harvest leaves during the growing seasons. 